\title{
History is the Plot
}

\author{
RAY GROVER
}

This contribution is in two parts. Firstly, a "documented historical fiction" account of Private William Nimot, the only frontline New Zealander in World Wars I and II to desert to the enemy; and secondly, an exploration of the choice of this methodology to cover historical events. Private Nimot was originally written as a chapter in the first draft of March to the Sound of the Guns (2008). Deciding it was not relevant to the topic of the book, I then cut it out, other than to make a passing mention of Nimot's unique status. It sat on the shelf for some years until I thought it might have the makings of a short story.

\section{Private Nimot}

It's Mum I miss most and then Dad and my sisters and brother. The Tararuas too, their tops white in winter. Nothing like them here, flat as a pancake. Don't miss much else. Or anyone. As a kid, right from the start, they'd tell me the football team was full and then they'd call for players. They'd have kept me out of the Volunteers too if they'd had their way, but I joined, the Carterton Rifles in '07 when you bought your uniform and voted for officers and NCOs.

Herbert Hart and I joined at the same time, foundation members. Hart was elected lancesergeant because he'd been to South Africa - and come back without firing a shot. I'd voted for him and again when he stood for lieutenant. A lot of good it did me. I know Hart's father, worked with him as a labourer, as he was until the day he died, but Hart knew who to marrya farmer's daughter whose father has a street named after him in Masterton.

My father was a farmer. Mum and he landed in New Zealand with only the clothes they stood up in. They came to what they thought was a free country where people could make their own way under British justice. Which is why my father paid for my uniform and changed our name from Nimodt to Nimot. Mum and he spoke German and their English wasn't up to much but they put their backs into it and made a farm out of swamp and bush. First-rate land that these days would turn a pretty penny.

I did my share of toil. Worked on most farms round the district. But it was always the same: start okay but after a month or two the boss would pick on me. All except one. We began okay and stayed okay but once the cows were dried off, he couldn't keep me on over winter. 'Come back in the spring,' he said, but I got into a bit of trouble: 'wilfully damaging property'. It didn't get into the paper but everyone knew about it. You'd walk along the street and you knew people were looking at you.

And my health was never the best, though it was a waste of time going to a doctor. Two in town and one as bad as the other. They knew about Oringi too; both of them brought it up. 'How do you know?' I said. 'Who told you?' They said it was written all over my face.

It was after the Oringi camp in 1909 that I left the Volunteers. It was the second camp I'd been to. The first was okay. Under canvas, field exercises over the hills - a change from attention, stand at ease, attention, slope arms, in the drill hall. But at the second camp, in the tent, on the 
Saturday night, they caught me. Everybody did it but they wouldn't admit it. I couldn't help it, had to do it, on the palliasse. Everyone in the camp knew. Big joke. Said I'd go blind.

When compulsory Territorials came in, Hart joined and got promoted. Others became NCOs. Nobody asked me to join. I wouldn't have gone anyway and they couldn't make me because I was over the age by then. But the war came and Mum and Dad reckoned going off might settle me down. We were told stories of fighting for British justice, Huns bayoneting babies and hanging nuns on bell clappers. I was feeling crook again so I went to the bloody doctor. Nothing wrong the army can't fix, he said.

I volunteered but they took their time calling me up and while I waited it was: 'What are you, a single man, hanging around for?' 'Don't like shooting your relatives?' And so on. I didn't get away until a year after war was declared. They made me a stretcher-bearer in the $1 \mathrm{st}$ Wellingtons. In the Volunteers I'd been a rifleman. When we got to Egypt the other boys went to Gallipoli, but not me; I was kept back doing fatigues. No one said why. Sand and flies, saw a bit of Cairo but what can you do in Cairo on a private's pay? When the battalion came back, what was I? A bloody shirker and just wait until we get to France for a crack at your cousins.

After landing in France went up to the line from Armentières. We took over from the English who told us if we'd leave Fritz alone, he'll leave us alone. What did we do? Banged away from the start. And what happened? We got more than we gave. And raids, the Gallipoli men said they knew about raiding but they didn't - I know, I carried them back. No talk of me being a bloody Hun out in no man's land. And no thanks when we were back. Instead they went on about there being too many casualties because somebody told the Hun we were coming. Now I was a 'bloody Hun spy'. Some made out it was joke but it wasn't. And it was the same at home. Mum wrote in her letters it was best if they didn't go anywhere unless they had to because people wouldn't speak to them and when they did they called them spies. It didn't matter that Mum and Dad had been in New Zealand forty years and that the only Germans I'd ever met in my life were them and that I was shelled day in and out.

Every so often we'd be pulled back from the frontline and given a spell in Armentières, except that most nights we'd be carrying up barbed wire or ammunition and repairing parapets or putting out more barbed wire, rain or fine, shelled or not. The night before another turn at the front, I met up with some Rifle Brigade boys. They were good blokes, friendly and after a spot or two when they asked who I was, I told them. They said they'd heard about me and that was that and we went on drinking and chatting and I overstayed my leave by half-an-hour. The provosts got me and next morning it was Hart who I was brought before, now Lieutenant Colonel Hart, $\mathrm{CO}$ of the battalion. Did he remember when we were in the Volunteers together, he a labourer's son and me a farmer's? Did he what? Fourteen days' Field Punishment No. 2 it was and told if we hadn't been going up it would have been fourteen days in the Field Punishment Centre. 'You're lucky,' he said and took me out of the stretcher bearers where I was just getting to know a couple and put me in Hawkes Bay Company. 'You won't get away with anything now,' was the welcome they gave me. And I was now a rifleman.

We garrisoned what we called the Mushroom. It had been an outpost but then some officer had made it larger and joined it to the front line by a stretch of parapets so that it stuck out in the shape of a mushroom with a stalk and a head at the end of it. It was close enough to the other side to hear German spoken. I'd been there before with night working parties. Every working 
party had been there because it got blown to bits with every shelling. A good place to put someone you don't like. We were shelled day and night. A shell hit the parapet and buried three of us under sandbags. I couldn't breathe or move and my neck was twisted. They pulled me out by my legs. Of the other two, one had his back broken and the other killed. I crawled away and they left me until it was dark when they put me back on sentry duty. Couldn't turn my head for days.

The last day of June was the quietest since we'd gone forward. During the night I could hear the other side talking. Not loud enough to tell one word from another but enough to know it was German. Every now and then there'd be a laugh. Hadn't heard anyone speaking it since I'd left home and it set me thinking. There was a corporal and me on sentry duty. About an hour before dawn I told him I felt sick and was going to throw up. He said go to the next bay along and do it. I went there and after putting my rifle and gas mask down, climbed over the parapet and crawled under the wire. I'd been in no man's land before, not just as a stretcherbearer but also at night hunting for souvenirs to sell to rear echelon men in Armentières. Like then, I had to be careful: any sound could bring a bullet. Once out I lay still and put on the stretcher-bearer brassard I still had. As I crept into long grass, I couldn't see much but kept going. Once I was in the clear, I looked back and couldn't believe it. A few yards from where I'd crawled through, the grass was moving-someone sneaking for our lines. Best of luck to you, I said to myself.

I crawled to the edge of German wire and then along it, looking for a way through, knowing there must be one. It would be dawn soon but I could see enough to make out the German parapet. It wasn't sandbags like ours, more of a steep slope of ground. I saw a shallow trench leading under the wire. I hurried to get in it; the battalion would be missing me soon and I had to find cover. One of my boots kicked a tin can. 'Halt! Who are you?' It was a German sentry. I crawled into the trench. Just in time. Rounds whipped through wire above me, not from the German side, but from behind, they started it; rapid, the Lewis gun too. If I'd raised my head I'd be dead-by my own people.

The Germans fired back, some into the wire. You couldn't blame them but they got close. It went on for I don't know how long but after it stopped I lay where I was; if I moved, one side or the other would shoot me. It was daylight by then. There was no choice-either be a prisoner or be dead before the day was out. And I was hungry.

I called out in German, not too loud. Then a bit louder:

'Don't shoot, I surrender.'

'You surrender, Tommy?'

'Yes.'

'Stand up, Tommy.'

'If I do, the New Zealanders will shoot me, my own people.'

'New Zealand Tommy?'

'Yes.'

'Where are you?'

'In a trench going under your wire.'

'Sit up, New Zealand Tommy.'

I did, expecting to be hit by a bullet.

'Put your hands on your head.' 
The voice was closer now and I wondered when someone on the other side would see me while I waited. The muzzle of a Mauser was pressed behind my ear. 'Show your face, Tommy.' I turned my head, the muzzle brushing my ear, to see the man aiming along the barrel with his finger around the trigger; another man beside him was aiming too. 'Roll on your back, Tommy. Keep your hands on your head.'

I rolled over, the muzzle now under my chin. The other man poked at my pockets with his rifle: 'Any hand grenades or a pistol?'

'No, no, nothing.'

'You better be speaking the truth, New Zealand Tommy.' He poked at another pocket. 'What's that!'

'Tobacco, my tobacco tin,' my throat going tight.

'Don't move.' He reached out, opened the pocket and pulled out the tin. It was shiny and I hoped it wouldn't flash in the sun. My legs twitched. He laughed. 'On your belly, Tommy, crawl.' I asked where and he said forward and when the trench turned he told me to turn. That's how we went under the barbed wire, the Mauser muzzle close and me wondering how tight was the finger around the trigger and if he'd bump into something.

They searched me. My throat was as dry as it's ever been and a sentry let me drink from his water bottle. Taken to a subsidiary trench, I was searched again but there was nothing to find except my paybook and I was given back my tobacco tin. I opened it and offered it to the man who'd taken it. He laughed again and filled his pipe. There was plenty left when he handed it back but it was the last decent tobacco I'd smoke for a long time.

An officer questioned me. He was like any officer. They gave me breakfast - black bread like Mum used to bake when she could get rye. I stayed three weeks in their rear trenches. They were good men, Saxons. They didn't like being there and made no secret of it. If anybody had talked like them from where I'd come from, he'd have been put on a charge, double quick. 'Stupid New Zealanders,' they said. 'Before you came, it was live and let live. We are Saxons and we only shoot if somebody shoots at us.'

The next night the Wellingtons raided. I was too far back for them to collar me. The Saxons didn't like it because they had to raid in return. They brought back prisoners but I didn't see them. Another Wellington raid followed but they didn't get far and again the Saxons had to raid in return. I stayed with them until they were relieved. They asked about New Zealand and my home but not why I'd crossed. They left that to the officers. I told them about Egypt and Cairo. We had some laughs about that. I was glad to get out of the trenches and the shelling but sorry to leave those boys.

I was put on a train to Westphalia. There was another New Zealander in the compartment. His name was Rowe and he asked where I'd been captured. It was a change to speak English so I told him the Mushroom. He said the Canterburys had relieved the Wellingtons at the Mushroom and he'd been caught there in a raid. I said I'd heard the raid had been pretty rough. He asked where I'd heard that:

'From the lads who'd been it.'

'Germans?'

'I was in the German trenches for three weeks.'

Journal of New Zealand Studies NS27 (2018), 147-161

https://doi.org/10.26686/jnzs.v0iNS27.5181 
'How was it you were there for so long?' His tone was doubtful.

'I don't know' - and still don't.

'How did you become a prisoner?'

I explained that I'd been taken in an outpost in no man's land. He pointed to the brassard I was wearing and said no man ever went on outpost duty wearing one of those. I did, I said.

'You didn't give yourself up, did you?' he demanded.

'What makes you say that?' I should have kept my trap shut but speaking English again made me talk.

At the next station I got out with my guard and we stretched our legs on the platform along with other guards and an officer. I could see Rowe staring at me from the compartment. Serve him right. If he hadn't been so nosy I could have got him out for a walk.

At the camp in Westphalia an officer questioned us again. I repeated what I had told in the trenches. Rowe yelled I shouldn't be telling things like that. I said I was telling no more than what I'd heard German prisoners telling our officers. To shut him up I spoke to the officer in German. Next day I met Rowe again. He asked what I was doing. I said I had a pass and was going outside for a walk. He went off the deep end, saying I was a deserter and when the war was over I would be shot.

The next day they sent me to a camp with only British in it. The food wasn't good. Other prisoners got food parcels but not me. I wrote to Mum and Dad. No parcels came, or letters. I also wrote to the British army about parcels. When the other prisoners asked why I didn't get any I answered truthfully that I was as much as a prisoner as they were and I didn't know. They looked at me in a funny way and talked about how even deserters who stayed behind the lines were shot. Not all were like that, some went to the Senior British Officer and said I should get parcels too but I went to the camp commandant and asked if I could be moved. I thought they'd forgotten about it but one day I was put on a train for Assenheim, near Frankfurt, and sent to a farm. It wasn't special treatment; plenty of other prisoners were on farms. Like at home some farmers were okay and others wanted the last sweat from your brow. Mine was better than being in a camp. We ate okay, nearly as well as at home.

I was there a couple of years and one of my jobs was to keep the house garden going. It was after the Armistice and I was digging up a late crop of potatoes. German soldiers were coming home but on that day a motor ambulance drove up that wasn't German. I didn't stop digging. I knew the rules: no prisoner could be made to return who didn't want to. I kept my head down but I could still see an officer getting out of the ambulance and walking across the paddock to me. He wasn't wearing a pistol and on his arm was a Red Cross brassard. Behind him was a Medical Corps sergeant:

'Hello, soldier.'

'Stay where you are.' Without thinking I was speaking English.

He stopped. 'Private William Nimot?'

'Who are you?'

He said Captain something or other, New Zealand Medical Corps. 'Are you Private Nimot?'

I looked at the ambulance. It could be full of provosts. 'What's it to you?'

'Time to go home.' 


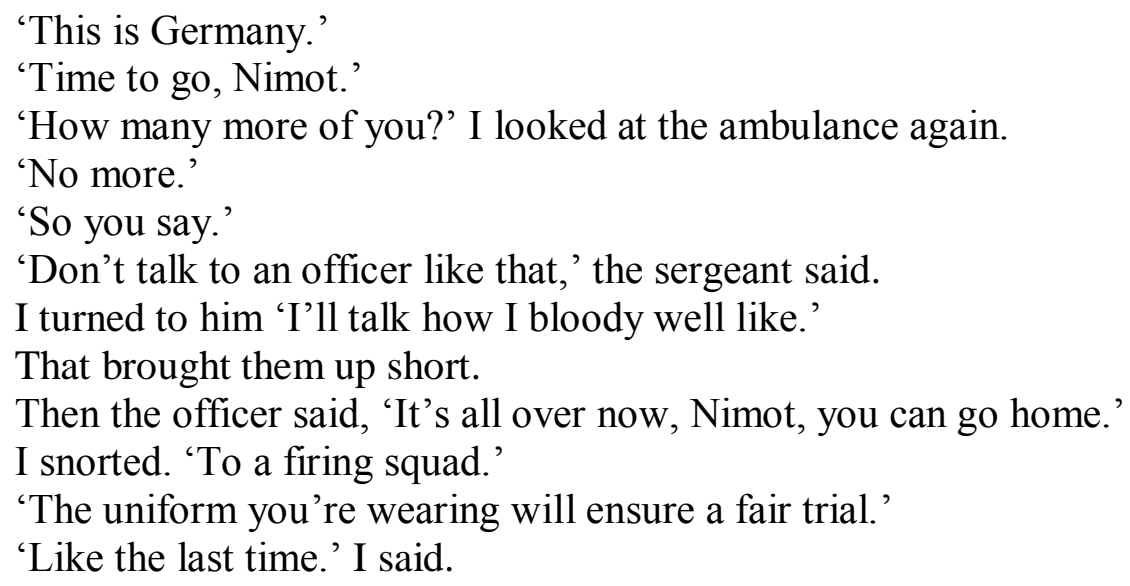

As for my uniform, I was down to only a tunic that long ago had seen better days - like a lot of clothes in Germany at the end of the war:

'What? I don't know anything about that. I've been sent to collect soldiers who were taken prisoner so they may return home,' said the captain. 'I don't deny there's a charge of desertion against you...'

'I'm not a deserter.'

'Then you have nothing to fear.'

'There'd be a court martial,' I said, 'a New Zealand court martial.'

'Which will assess the evidence impartially.'

'Like the last time when bloody Hart gave me fourteen days' No. 2 for overstaying leave by half-an-hour?'

'As I've said, I don't know anything about that. This time you'll have a fair hearing and an officer to defend you.'

'An officer to defend me? Better him,' I pointed to the sergeant, 'and I'd trust him no further than I'd kick him.'

'Watch it,' said the sergeant.

'What're you going to do about it?'

He went quiet:

'I'm a prisoner of war,' I said to the officer.

'And if you're a man of honour you'll return to clear your name.'

'You guarantee that?'

The officer nodded. 'You have the guarantee of a fair trial.'

'Not at a New Zealand court martial.'

'You have no reason to say that.'

'I have a very good reason.' I looked him in the eye. 'If you can guarantee British justice I could change my mind.'

'Of course it'll be British justice.'

'Not at a New Zealand court martial.'

'You've been living off the fat of the land,' said the sergeant. 'Not like the poor buggers in the camps.'

'The countryside's crawling with prisoner of war farm workers.'

Again no words from the sergeant: he knew it was true.

'And if I hadn't been on a farm I'd have starved. No parcels, you know that. No mail either. I wrote to my mother and I know she writes to me.' 
'Maybe we could get a message to your mother.'

'And tell her I'm a deserter? I'll bet you've told her already - and everybody else.'

'Give me her address and I'll see what I can do.'

'All right. Tell her I'm near Assenheim, in good health and I don't get any pay. If I was a deserter I'd be rolling in it, but I'm a prisoner.'

'There's over two years pay waiting for you.'

I laughed. 'In lead.'

'Give it a try.'

'Only with a guarantee from the British government.'

$* * *$

About six months later a sergeant major showed up. By then I'd had enough of the farmer and had taken a job at a cheese factory in Assenheim:

'10/2719, Private William Powell Nimot, 1st Wellingtons?'

'I'm Bill Nimot.'

'I've come to take you back.'

'We'll see about that.'

I walked past him into the factory. At the end of the shift he was still there.

'This won't go well with you. Keeping a warrant officer waiting.'

'Bugger off.'

'Mind your language, soldier.'

There was a corporal in the driver's seat of the car. There were local people around and they were watching. Whether they'd do anything if I was taken I don't know:

'You can't make me go.'

'Be easier for you if you did.' Taking me for a fool. 'There's a civil war going on. You should think about that, Nimot.'

There was fighting: mutinies, riots, street battles in Berlin and Bavaria; returned soldiers with no jobs; people hungry, stealing to live.

'I keep to myself.' There'd been trouble in Assenheim too.

'What makes you so sure? The Reds and Freikorps; both on the rampage-one's as bad as the other.'

'I keep to myself.'

He shook his head. 'A British soldier? You're fair game.'

'The only people out to get me are you lot.'

He changed tack. 'Have you written to your mother lately?'

Trying to surprise me, but after the last visit, I was ready:

'You know our letters are stopped.'

'Don't you want to know whether she's alive or dead, and the rest of your family?' He went on but I turned my back on him.

That was years ago. Things could be better but I'm getting by. I have a family, a house in the village, and still work at the factory. I get letters from one of my sisters. She's never married and says during the war they wrote letters and sent parcels. The police did the family over regularly and neighbours didn't want to know them. Mum and Dad were driven to the grave. 
She still lives in the house but keeps to herself. The farm was sold for returned soldiers. No share of the proceeds came my way.

As for here, Germany, the Nazis have taken over.

\section{My Approach to Documented Historical Fiction}

Some years ago I had a beer with a man who had been a top-line League player. After he mentioned that he had played the other code until he was in his late teens, I asked what made him change. He replied, "I was in the army and the battalion's League team was a man short and they asked if I'd fill in. I said okay and in five minutes I knew this was the game for me." When asked why I write first person documented historical fiction my reply is along the same lines. Years ago I happened to be reading a translation of Pushkin's short stories and what charmed me was his ability to create the impression of being with an old friend who after sharing a couple of single malts turns to you and asks "Did I ever tell you about..." and off he goes, recounting a story which, even when it is not in the first person, feels as though it is, thus establishing a personal connection between the reader and the story. I tried it out and it only took half a dozen pages to know this was the style for me. As for my way of writing history, all I might do is offer justifications after the event. They might or might not have some validity.

As a boy I read a lot. My father was a country schoolteacher and all the reading that was available was what was held in the school where he happened to teach at the time. Given that this was in the 1940s, there wasn't much to choose from, except that right from the beginning I looked for stories about people. That I found a fair number of them were histories didn't worry me; so long as people figured in them, they were read with the same interest as novels. Whether fact or fiction was irrelevant. The practice has continued. I now have a library of my own and just under half are history and the rest novels. It was in my last year at school that I first read War and Peace and decided it was the greatest book I had ever read. Hundreds of books later, I have modified my opinion a little - it is one of the greatest books I have read. However, fiction derived from authentic evidence from the past continued to fascinate me.

Another Man's Role (1967), my first novel, was heavily influenced by John Mulgan's Man Alone (Hamilton, 1960), and told a more or less contemporary story of a man who eventually committed a murder. While I was writing it I became friendly with a Justice Department official who specialised in research. He offered me access to the personal files of men who had been hanged during the National governments of the 1950s. Although utterly dispiriting, the files plunged me into situations I would never have experienced otherwise and opened up a range of research sources I previously had known about only by hearsay.

Soon after I read a notable historical novel which deserves to be better known: The Cross and the Sword, by Manuel de Jesus Galvan. First published in 1882, this Caribbean classic, which tells of the extermination of indigenous Indians following the arrival of Columbus, is based on the findings of the sixteenth century Dominican historian, Bartolome de las Casas. It too was highly influential - the final pages contain 168 endnotes referring back to de las Casas. Why not, I thought, as I put the book back on the shelf, write a documented historical story rather than just a "normal" historical novel where so often the events recorded are little more than background? Why not take a step further and write history in the form of a novel?

By then I was in my eighth year working at the Alexander Turnbull Library, in the midst of a mass of research materials relating to our history. The decision to use these for a book therefore 
is hardly surprising. Although the job kept me fully occupied during the day, I made time to research and write in the evenings and weekends. Concomitant with this I saw no reason for also not committing myself to the same research standards expected from the more reputable users of the reading room. The combination of paid work, research and writing, however, resulted in the production of only three further, admittedly lengthy, books in that genre during the next 50 years. During some of those years, particularly when I held the position of Chief Archivist, I was lucky if I could spill out a few lines on the odd weekend - until retirement freed me up.

Like everyone else, my first step towards writing a book is to find a topic. In the case of Cork of War: Ngati Toa and the British Mission (1982), it was my eye lighting on a Heaphy watercolour sketch of the fighting chief of Ngati Toa, Te Rangihaeata. This was still in the years when people referred to the Wairau 'Massacre' in which Te Rangihaeata participated. I looked at the picture and felt that he didn't seem like a murderer to me and wondered how it had come about that the settler community regarded him as one. My first problem was that I wanted a contemporary European narrator (feeling that I lacked the imagination, knowledge and experience to cast a Māori in such a major role) who was friendly with him. Given the almost universal hatred in which Rangihaeata was held by the settler community it took me a while to find one, and I only picked him up when, looking for something else, I came across a passing remark by James Cowan that such a person was Jock Niccol, a Kapiti Coast whalerI have since learnt there was another, like Jock a man who had personal dealings with him. I was lucky in my find as most whalers, having left no written records either by or about them, have become historically anonymous. Jock had two things going for him: he was married to a notable Kapiti Coast chieftainess, and when the whaling ran out kept a pub where he became enough of a character for people to occasionally mention him in their writings. A job, a wife with whanau connections to Te Rangihaeata and other iwi notables, and a local resident, gave me the base for my creation of Jock. I say creation because I then, by making him the narrator, added a lot more to him than what he probably had, and conversely, perhaps a lot less about his personal qualities. In other words he is, as a person, more fiction than fact, except that his "fiction" is taken from facts derived from research information. And if you subjected the activities I have him perform to cold analysis he would have had to be a very alert and energetic fellow - although I seem to have avoided putting him in two places at once.

What set me off on my March to the Sound of the Guns/Province of Danger duology (2008, 2018) was not quite as dramatic as the Heaphy picture. Rather it was writing a review of Chris Pugsley's Gallipoli and then being asked by Chris to do an article on the commander of the First World War New Zealand Expeditionary Force, General Godley. This got me interested in that war and the one that followed 25 years later. But this time I used five narrators (only one of whom was "real"), each presenting his or her own point of view, because a wider coverage was needed than could be supplied by a single narrator. On top of that, to enhance veracity, I also had to write in five different styles, each reflecting the temperament of an individual narrator - a combination of devices stolen from none other than William Faulkner. It took me a little while to realise that what I was doing was presenting my story on the basis of "I was there and this is what I saw, heard, felt, feared, etc", thereby, I hoped, creating a feeling of immediacy by writing history in the first person.

So I have people telling the stories and, as I mentioned earlier, from the beginning they have been stories where the emphasis is on people. Hence I not only write history as if it were 
participants telling it, I also focus on what other people did and did not do, using insight and imagination to empathise with them. I do not, however, let insight and imagination range beyond the bounds of what research has revealed. This is not as easy as it sounds and I have to confess that now and then I have put twentieth-century thoughts into nineteenth-century people. All I would note is that since this was pointed out to me, I have tried to keep within the bounds. This also means recognising and writing within the blind spots of the time and the place even when presenting an otherwise sympathetic character. (The converse also holds being aware that we must have unsympathetic characters too.) This is just one example of the need for research in depth: you cannot write convincingly about people and the influence a particular time and place had on them unless you acquire a thorough knowledge of that time and place. Indeed one might go as far to say that a documented historical novel is written when you want the environment and the events which occur in it to be more than just background to the characters whose story you are telling.

At times, in this sort of writing, events tend to be - if not more important - at least as important as the characters in the development of a plot. It should not be surprising therefore that many of the decisions made by the characters in this type of novel are in reaction to the circumstances in which they find themselves. This is especially so when one takes into account that when it comes to a war, most people get caught up in it, rather than choose to participate, and even amongst those who believe they have made a choice, more often than not it is because they have succumbed to social or political pressures. And once involved, the individuals have their lives circumscribed by huge impersonal forces beyond their control. It is not surprising therefore that a publisher turned me down because he felt too many of the characters were acting in response to situations rather than creating them.

And not only publishers. An old and dear friend, who otherwise quite liked March to the Sound of the Guns, criticised it because one of its major characters, a narrator who is dominant in the first part of the story, was killed well before the book came to an end, i.e., the death intruded into the plot. My response to this was first, that the reality of war is that people to whom we have become close can get killed, and secondly that I had written about this man because my imagination had been stimulated by the combination of his personality and the events that led to him being killed. Indeed far from the plot being sacrificed for history, history was the plot.

The consequence of this is that the author tries to exercise the same discipline as if he/she were writing a narrative history (that is, the practice of writing history in a story-based from). If one does not research thoroughly one may as well be writing what some have termed "entertainment history", a phrase, unfortunately, applicable to a vast number of historical novels. Thus the validity of a documented historical novel will rest on two factors: the depth of the research that has gone into it - as with narrative history-and the quality of characterisation and writing - as with a conventional novel.

Moreover, as with narrative history, the author has to ask, is what I include relevant to my historical plot or is it a diversion? That is, the author edits the amount of historical information in his/her book on the same basis as a conventional historian does-it is retained insofar as it is relevant to the topic of the book. For example, if writing about New Zealanders on the Western Front, one writes about Canadian involvement there only when it has relevance to the New Zealand experience, despite the many interesting things a "normal" novelist could write about, for example, the personality and performance of the Canadian commander.

Journal of New Zealand Studies NS27 (2018), 147-161

https://doi.org/10.26686/jnzs.v0iNS27.5181 
There is a further hurdle: the commonly held view that historical novels tell stories where the historical aspects are taken lightly; at best being no more than background and at worst where history is misrepresented or perverted on the grounds that a novel's plot overrides any need for accuracy. Such novels abound to the degree that they are far more common than those where history is given the respect it deserves. If you are a writer of Shakespearean quality that doesn't matter, but for the rest of us it really queers the pitch. That being so I find myself having no option but to declare sympathy with those who have doubts about the validity of the role of historical novels as a serious genre. No wonder that the most common complaint made against historical fiction generally is that you don't know what is factual and what is imaginative.

Various methods have been suggested for countering this, one being to write a roman á clef so there is no illusion that one is reading historical facts - which would entail the absurdity that Hilary Mantel's yet to be completed Wolf Hall trilogy would have had to have been written about people with names like Thomas Crosswell and Alfred the Eighth. Another is that the fiction and fact should be distinguished by printing one form in italics and the other in a regular font. I tried this: when writing about the events and high level decisions that led into major battles on the Western Front, I used italics. They were okay, I suppose, but what font do you use when writing a dialogue which, although it actually might never have taken place, is very closely based on fact, or when you have a sentence which is part fact and part fiction?

The only solutions appear to be: first, relying on the intelligence of the reader. Surely anybody who has wits enough to read Hilary Mantel's historical books is immediately aware that the details of Thomas Cromwell's thoughts, feelings and conversations are interpretations, and as such are not expected to have the same level of accuracy as the fact that Henry the Eighth had Anne Boleyn's head cut off. Mantel's presentation of Cromwell and Henry should therefore be assessed in the same way as any other historian's presentation of historical characters - in the light of current research do they ring true? Secondly, the author can make an explanatory statement. In the preliminary pages of my latest book, Province of Danger - perhaps as a consequence of writing this piece - I state: "All thoughts, feelings, conversations, descriptions and events that relate to political and military matters have been sourced from items in the Bibliography. Battlefields and other localities mentioned were examined in person." In retrospect, I could have been more accurate about this. It was inserted in haste as the text was going to press and, not being as alert as I was a year or two ago, I omitted "Most" before "Battlefields"; local politics prevented me from visiting sites in the Western Desert. If there is ever a second edition I shall amend accordingly. The third solution, and maybe this really is the only way to counter the common conception of historical novels, is for their authors to grant history the respect it deserves.

So, why bother about having to fulfil the requirements of both novelist and historian? The answer has been summed up by Hilary Mantel who says it is done so that "the dead can be brought back to life." Indeed she goes further: "You have the authority of the imagination, you have legitimacy. Take it. Do not spend your life in apologetic cringing because you think you are some form of historian. The trades are different but complementary." 2 As one who does see himself as "some form of historian" I nevertheless have no issue about what I write being "complementary" to narrative history - provided "the authority of the imagination" is derived from adequate research. I can also understand Mantel's assertiveness, given some of the remarks made about documented historical fiction by those historians who cannot see 
beyond their personal perspectives - along with her also warning against romanticising the past or seeing it as a gory horror show. ${ }^{3}$

In Private Nimot I have made some concessions to fictional forms and contents. First I have Nimot talking about "British Justice", a phrase much more common 100 years ago than now. I came across it being frequently used in the files of dissenters who were against pre-1914 compulsory military training; they maintained, on the grounds of "British Justice", that they were not getting a fair deal. The second concession is the last sentence in the story where Nimot remarks that the Nazis have taken over. This is a fictional device, but also a post-World War I/pre-World War II fact. It provides an end to a particular episode in Nimot's life and the beginning of a new one. (I have heard anecdotally that his sister and he resumed correspondence after the war.)

Although I have tried to explain what I mean by "documented historical fiction", in no way is it a category I would swear by. At the most it is a rough and ready explanation, but preferable to the ugly neologism "faction" that duplicates the spelling of a useful existing word. Neither, because it implies higher writing skills, do I buy into "creative non-fiction". If that were so, how would you classify Gibbon? Or, closer to home, Beaglehole or McCormick: two of our finest prose writers, meticulous researchers and by no means devoid of imagination? Finally, except in the broadest and most flexible sense, I have doubts about literary genres and reject entirely those who attempt to define them as if they were biologists classifying flora and fauna, and then have the temerity to complain about literary pieces that do not fit their formulae. All that counts is whether or not an individual book or story works within its own criteria - if it includes a substantial amount of history, it should be assessed accordingly.

\section{Appendix}

The events detailed in Private Nimot, from Nimot's pre-war years in the Wairarapa to a confrontation in Germany, are derived from the following sources:

Nimot file, Archives New Zealand AD 10/5/4;

Crawford, J.A.B, 'Hart, Herbert Ernest 1882-1968', Dictionary of New Zealand Biography Vol III, Wellington, 1996, pp. 201-2;

Pugsley, Christopher. On the Fringe of Hell: New Zealanders and Military Discipline in the First World War, Auckland, 1991. pp77-83, 91-2;

Stewart, H. The New Zealand Division 1916-1919: A Popular History Based on Official Records, Auckland, 1921, p53.

Below are excerpts from records filed (mostly under D24/149) within the Archives New Zealand classification AD 10/5/4, grouped sequentially in the four relevant localities:

\section{A Wairarapa}

Parents born in a country district near Lauenburg, Germany.

Nimot was before the Magistrate's Court on 5 March 1914 and convicted of wilful damage to property... One of the facts I elicited out of her [Nimot's mother], was that this boy was not quite right in the head. I do not mean to say that he was actually mentally deficient, but apparently he had been attended by Dr Johnston of Carterton and Dr McHardy, for a good while, and they could make really nothing out of him, he being, if anything, somewhat of a waster, and there was a rumour that they said at last 'you had 
better go to the war, and see if it will do you any good'. The boy, being somewhat worked up, according to his mother's statement, by the description of German atrocities, decided to enlist, which he did.

From conversations with other soldiers from this district who were in camp with Nimot I was led to believe he was hated by those who knew him. [taken from report by Constable A Gregor, Carterton, 14 July 1916.]

A Carterton farmer states that the deserter worked for him and seemed a decent fellow. After having been in camp for some time, he became very enthusiastic over the war and remarked that as a New Zealander, he was ready to settle 'any German he ran up against at the war'. [Taken from a filed New Zealand Times clipping, 26 August 1916.]

I really believe Nimot's father and mother to be entirely innocent. I have known Nimodt, snr, and his wife, and the remainder of the family for nearly 20 years. The old people are hardworking, honest, peaceable and thoroughly decent people.

The plain fact is that Nimodt, the deserter, is erratic; cause: masturbation. One of your sergeants major reported adversely, when this young fellow went into camp previously. [Taken from letter by J. T. M. Hornsby, MP for Wairarapa and Mayor of Carterton, to James Allen, Defence Minister, 31 Aug 1916.]

\section{Deserting the Trenches}

About 2.45am Nimot complained to me of feeling sick and expressed his intention of going into an adjoining sap to vomit. About 10 minutes after this $\mathrm{Cpl}$ Solvander passed a remark that he thought he saw a man going over the parapet on my left. I remarked it could not be possible as a sentry, Nimot, had just gone along there. As there was an Engineer's fatigue party working on a new sap, we came to the conclusion that it must have been an Engineer. About 5 minutes after the Cpl left me I went in search of Pte Nimot and discovered his equipment and gas helmet on the edge of the parapet and I noticed footprints leading to and over the parapet. [Taken from Court of Enquiry minutes, 1916: first witness "Pte Firth, 9 Hawkes Bay Coy, 1 Bn WIR 29 June 1916”.]

No signs could be seen of Nimot. Rifle fire was ordered to sweep NML, and I went back into No 2 locality, and ordered the Lewis MG there to do the same thing. [Taken from Court of Enquiry minutes, 1916: third witness "2/Lieut Percy, 9 Hawkes Bay company, WIR".]

\section{Prisoner of War}

I met Pte Nimot of the Wellingtons on July 16 in a pow camp. He was separate from us. He came into camp with a guard. He was separate from us in the camp and I did not see him in camp again.

The next time I saw him was when I was going from the camp to the train at Douai. I was speaking to him when we got on the train to Westphalia.

I asked him how it was he was so long behind the German lines.

He replied that he been three weeks in the German front trench. When I asked him why, he said it was his business not mine. I asked him how he became a prisoner, and he said he was caught in an outpost. He was wearing a Red Cross armlet in the train. I said no 
man ever went on outpost duty wearing a Red Cross armlet, and he said they did.

I said: 'You didn't give yourself up, did you?'

He replied: 'No. What makes you think that?'

Later he said to me: 'You better mind your own business', and then he walked out of the carriage.

When the train stopped at a station he got out and was speaking to German officers and soldiers on the platform.

When Nimot was being examined [by a German officer] he started telling the officer about our trenches and I stopped him. He said he knew what he was talking about. After that he talked to the officer in German. [Taken from 'Rowe Statement', 17 Dec 1918.]

\section{Confrontations}

When Pte Nimmot mysteriously disappeared from our trenches... certain circumstances and behaviour of enemy artillery a few days afterwards led the authorities to conclude he had deserted.

Possibly Pte Nimmot also thought there was little chance of his comrades in arms ever seeing him again. But in war it is ever the unexpected that happens.

When Germany was beaten and the armistice declared, a section of the New Zealand Medical Corps went with 2nd Army pows [prisoners of war] communication into Germany and there in a village called Assenheim between Hanau and Friedberg our Medical officer and his men came face to face with Pte Nimmot still clothed in a portion of his NZ uniform and industriously digging in a German garden.

He showed no disposition to join the NZ Division. Indeed he absolutely refused to be conveyed back to British lines and said he would not leave Germany at all unless he got some kind of guarantee of justice from the British government. What guarantee he required he either did not himself know or would not state it.

He accused several officers who were in his Battalion at the time of his disappearance with treating him harshly.

He did not say he was a deserter but always referred to himself as having been taken prisoner.

He is apparently the one British prisoner who is unanxious to get out of Germany.

He, however, wishes his people to be informed of his whereabouts as he was short of money.

His physical condition was good.

The officer who met him under such strange circumstances is convinced that, apart from forcible measures, nothing will induce him to come back to the British area or return to NZ. [Taken from telegram received from official war correspondent Ross, 4 Feb 1919.]

I was detailed to proceed to Germany May to September 1919 to locate and bring NZ prisoners of war... I was instructed to locate the whereabouts of W.P. Nimmo who was alleged to have deserted ...

I located Nimot at Assenheim... He is employed in a cheese factory and appeared to be prosperous although worried a great deal. He alleges he did not desert or give himself up to the enemy. He further states he would willingly surrender and submit himself to a court-martial provided he be tried by English officers and no NZ officer be on the courtmartial.

I have reported the above facts [and] I am prepared to obtain Private Nimot ... if instructed to do so. [Taken from statement by Sgt Maj R.M. Bell.] 


\footnotetext{
${ }^{1}$ https://www.theguardian.com/books/2017/may/20/hilary-mantel-swaps-historical-fictionalternative-facts-radio-4. May 20, 2017.

${ }^{2}$ https://www.theguardian.com/books/booksblog/2017/apr/04/hilary-mantel-historical-fictioncringing Apr 4, 2017.

${ }^{3} \mathrm{https}: / /$ www.theguardian.com/books/2017/may/20/hilary-mantel-swaps-historical-fiction-alternativefacts-radio-4. May 20, 2017.
} 